\title{
Language Use in Computer-Mediated Communication: An Investigation into the Genre of Workplace Emails
}

\author{
Mohammad Awad AlAfnan \\ Head of English Language Department \\ BMIC, Kuala Lumpur, Malaysia \\ E-mail: mohammad_alafnan@bmic.edu.my
}

Received: 05-12- 2014

doi:10.7575/aiac.ijels.v.3n.1p.1
Accepted: 24-01-2015

URL: http://dx.doi.org/10.7575/aiac.ijels.v.3n.1p.1
Published: 30-01-2015

\begin{abstract}
This study investigated the moves and communicative purposes used in 522 email messages that were exchanged in a Malaysian private educational institute. Using Swales's (1990) move approach, this study revealed that email writers used fourteen moves that are mainly six framing and eight content moves. Content moves included four main, one intertextual, one supporting and two follow-up moves. The four main content moves reflected the main communicative purposes of the emails that are discussing issues, enquiring about issues, couriering (delivering) documents and informing about organizational and academic issues. The four communicative purposes varied in their structural organization, number of recipients and reaction to receiving the email.
\end{abstract}

Keywords: Genre analysis; Email communication; Rhetorical moves; Communicative purposes; Discourse community

\section{Introduction}

The use of email for business communication is increasingly becoming the phenomena these days (AlAfnan, $2015 a / 2015 b / 2014 a / 2014 b$ ). Since the first email was sent between two networks, researchers realized the communicative nature of this method of communication. Even though some researchers initially categorized email as a lean method of communication that cannot carry out organizational tasks (Daft and Lengel, 1986), other researchers using the same standard proved that email is used in organizations for task-oriented purposes just as any other rich medium of communication (Markus, 1994).

Previous investigations on the genre of email communication, which mainly focused on the emails exchanged in the business sector (Nor Azni, 2003/2006 and Kankaanranta, 2005), showed a great deal of variations. Some researchers categorized email as a pre-genre (Spooner and Yancey, 1996), while others categorized them as a single genre (Mulholand, 1999). Other researchers asserted that email may belong to a number of sub-genres (Kankaanranta, 2005). Following Swales's (1990) rhetorical moves approach to genre analysis, this study examines the genre of emails exchanged in a private educational institute in Kuala Lumpur, Malaysia. Thus, this study focuses on the rhetorical moves used in the emails and their communicative purposes. Specifically, this study examines two main research questions as below:

1. What are the moves used in the email messages?

2. What is/ are the communicative purpose[s] of the email messages?

\section{Identifying Genre}

The term genre was looked at and examined from different angles. Whether it was seen as "typified rhetorical actions based on recurrent situation" (Miller, 1984, p. 159), "how things get done, when language is used to accomplish them" (Martin, 1985. p. 250), or "a socially ratified way of using language in connection with a particular type of social activity" (Fairclough, 1995, p. 14), genre analyses examined reoccurrences in the correspondence. These definitions of genre are based on the focus of the analysis that should be carried out in order to identify the genre. For Swales (1990) and Bhatia (1993/2002/2004), however, the term genre refers to the "consistencies in the communicative purposes".

Swales (1990) argued that the traditional method of genre analysis that focuses on register does not explain the genre of correspondence. Identifying genre, according to Swales (1990/1998), should look at the rhetorical moves and the communicative purposes used in a correspondence in a [place] discourse community. To identify the moves, Swales proposed his "move-step" approach, which examines the communicative purpose of the correspondence. In addition to the communicative purposes, Swales (1990) emphasized the importance of the discourse community using the genre. Discourse community as presented by Swales, is different from speech community that is widely referred to in sociolinguistics. Discourse community, according to Swales (1990), includes a number of people, who have their common public goal of communication, have a common technique in their intercommunication, and use this technique in their communications whether it is to deliver information or give feedback. 
The use of the English for specific purpose approach to genre (ESP) has attracted a number of researchers in the last two decades (AlAfnan, 2015a; Askehave \& Nielsen, 2005; Lassen, 2006; Llopis, 2009; Yates and Orlikowski, 2002). After analysing their communicative purposes, Yates and Orlikowski (1992) recognized business letters, business memo, and business email messages as genres. Berkenkotter and Huckin (1995), however, stated that the traditional classification of genres is very general. For them, knowing the genre does not only mean knowing the topic and the content it should also include knowing the specified topic and the details of the communication. Genres should also be restricted in terms of time and place, therefore, business letters cannot be considered as a genre because they refer to a general topic that includes many ancillaries.

In a more recent study, Wang Ji-yu (2007), using Swales's and Bhatia's ESP approach to genre, analyzed a number of business letters in order to find out their types of genres. She concluded that business letters belong to three different types that are getting or sending information, persuading or negotiating and collaborating. In another study, LouhialaSalminen (1995), who studied business fax communication, referred to business fax as a single genre. LouhialaSalminen stated that writing a business fax carries a number of expectations regarding the form and the content between business partners. This means that the name of the sender may summon the purpose of the fax. Later on, LouhialaSalminen (1999) found that business fax can stand as an umbrella for a number of business fax subgenres like inquiry and order. Mulholland (1999) shared Louhiala-Salminen"s (1995) view of recognizing genres. She referred to workplace emails as a single genre. Mulholland (1999) strived to find the regularities of workplace emails as a genre, and she did not refer to any subgenres. Mulholland's motive of doing the study was driven by her desire "to describe and account for e-mail as a distinct genre in the evolutionary stage in one particular institution and in one set of communications" (Mulholland, 1999, p. 81: original emphasis). Friesen (2009), however, referred to electronic business communication in general including emails, blogs, FAQs as a single genre that includes similarities.

This shows that the majority of research conducted on the genre focused on business communication, while the genre of emails in the educational sector did not receive much attention. This study examines the genre of email communication in a private educational institute in Malaysia.

\subsection{Identifying Communicative Units}

To identify the communicative purposes of correspondence, Swales (1990) suggested his move-step approach. According to Swales (1990), the moves are bigger than the steps and they carry the intention of the communication. On the structural level, they could be extended from one to a number of steps. The steps, on the other hand, are smaller than the moves and they could be written in various grammatical forms. Every step, according to Swales, has a communicative purpose. In order to explain his move approach, Swales analyzed the rhetorical moves and steps in an introduction to research article (See Figure 1).

\begin{tabular}{|l|}
\hline MOVE 1: Establishing a territory \\
Step 1 Claiming centrality \\
and/or Step 2 Making topic generalization(s) and/or \\
Step 3 Reviewing items of previous research \\
MOVE 2: Establishing a niche \\
Step 1A Counter claiming \\
or Step 1B Indicating a gap, or \\
Step 1C Question-raising, or \\
Step 1D Continuing a tradition \\
MOVE 3: Occupying the niche \\
Step 1A Outlining purposes \\
or Step 1B Announcing present research \\
and Step 2 Announcing principal findings \\
Step 3 Indicating RA structure
\end{tabular}

Figure 1. The CARS Model (adapted from Swales, 1990, p. 141)

This shows that Swales's (1990) analytical framework mainly depended on rhetorical and linguistic units.

\section{Email Genre Analysis}

Genre analysis in this study is based on Swales's (1990) move-step approach. Examining the moves used in the emails showed that the writers have frequently used fourteen moves that are six framing moves and eight content moves. The framing movies included the identifying topic move in the subject box of the email, salutation, opening, pre-closing, closing and signature. The eight content moves, however, were four main communicative moves, one intertextual move, one supporting moves, and two follow up moves (See Table 1). 
Table 1. Moves in the corpus

\begin{tabular}{lllll}
\hline No & Moves & $\begin{array}{l}\text { Occurrences } \\
522 \text { emails) }\end{array}$ & (out of & Percentage \\
\hline 1 & Identifying topic & 520 & $99.6 \%$ \\
2 & Salutation & 442 & $85 \%$ \\
3 & Opening & 19 & $4 \%$ \\
4 & Referring to previous contact & 56 & $12 \%$ \\
5 & Requesting/ responding to request & 173 & $33 \%$ \\
6 & Discussing academic/ & 186 & $36 \%$ \\
& organizational issues & & \\
7 & Indicating enclosure & 89 & $17 \%$ \\
8 & Informing about $\quad$ academic/ & 74 & $14 \%$ \\
& organizational issues & & \\
9 & Providing extra information/ & 115 & $22 \%$ \\
& further explaining issue & & \\
10 & Requesting confirmation & 32 & $6 \%$ \\
11 & offering help & 28 & $5 \%$ \\
12 & Pre-closing & 96 & $18 \%$ \\
13 & Closing & 450 & $86 \%$ \\
14 & Signature & 488 & $94 \%$ \\
\hline
\end{tabular}

As Table 1 shows, the framing moves are the most frequent moves in the corpus. They appeared in at least 85 percent of the emails. The content moves, however, had a lower frequency. The eight content moves identified in the email messages can be categorized as main, intertextual, supporting and follow-up moves. The main moves refer to the moves that included the communicative purpose of the correspondence or the email as a whole. The intertextual move refers to the move that included reference to previous contact. The supporting move, however, refers to the moves that were used to corroborate the main communicative move of the emails. The follow-up moves, however, acted as a method to confirm the receipt of the email or offer help if needed. Interestingly, the four main content moves, namely, 'discussing academic or organizational issues, 'requesting and responding to request', 'indicating enclosure' and 'informing about academic or organizational issues' appeared in separate emails. Given that the identification of the moves is based on their communicative purpose, this indicates that the emails included four communicative purposes.

To name the different communicative purposes, the emails that included the 'discussing academic and organisational issues' move were named 'discussing messages', the emails that included the 'requesting and responding to request' move were named 'Enquiry messages', the emails that included the 'indicating enclosure' move were named 'courier messages' and the emails that included the 'informing about academic and organisational issues' were named 'informing messages'. Discussion messages occurred in 36 percent of the corpus, enquiry messages occurred in 33 percent, courier messages occurred in 17 percent and informing messages occurred in 14 percent (as shown in Figure 2).

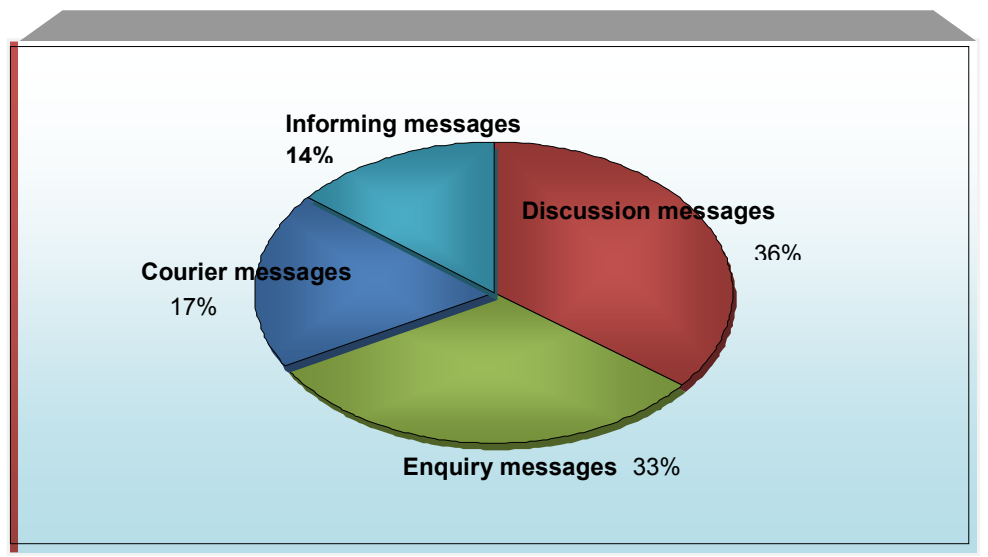

Figure 2. The communicative purposes of the email messages

\subsection{Discussion Messages}

Discussion messages refer to the messages that include 'discussing academic or organizational issues' move. 
Examining the use of these messages shows that they are always part of an ongoing discourse between two interactants regarding an academic or organizational issue. They are, in fact, the main communicative intention of the corpus as 186 emails (36 percent) belonged to this communicative purpose. Examining the characteristics of this communicative purpose reveals that discussion messages are always part of a chain. Even though the first reply may seal the point, the overwhelming majority of discussion messages created on-going chains as the first reply become the subject of the third email and so on. The length of chains ranged from two to nine email messages. It was found that 19 chains included two emails only, 29 chains included from three to five emails, and 4 chains included six to nine email messages. Given that the number of discussion email messages is 186 , this means that 38 emails, which equal only 20 percent of the discussion messages, were part of a send-reply chain. The other 148 email ( 80 percent of the discussion messages) were part of longer chains that included from three to nine messages. This means that the 186 discussion messages belonged to only 52 chains, which shows the conversational nature of the discussion messages.

Conducting the move analysis on discussion messages showed that these messages include nine of the fourteen moves identified in the corpus. The nine moves are six framing moves, one main move that carries the communicative purpose of this type of messages, one intertextual move that is used to relate the written email to other methods of communication and one supporting move that is used to give extra information about the attributed issue. Obviously, the main content move carrying the communicative purpose appeared in all discussion messages. Examining the use of the framing moves in discussion messages shows that identifying topic move, salutation, closing and signature moves were very common as they appeared in 100, 86, 91 and 96 percent, respectively, of discussion messages. This shows that the writers of this communicative purpose used a high level of framing formality. If the use of framing moves is considered more polite and formal than not using them, it can be stated that the writers of discussion messages were polite and formal (See Table 2).

Table 2. Moves in discussion messages

\begin{tabular}{|c|c|c|c|}
\hline No & Moves & $\begin{array}{l}\text { Occurrences (out } \\
\text { of } 186 \text { emails) }\end{array}$ & Percentage \\
\hline 1 & Identifying topic & 186 & $100 \%$ \\
\hline 2 & Salutation & 161 & $86 \%$ \\
\hline 3 & Opening & 16 & $9 \%$ \\
\hline 4 & Referring to previous contact & 33 & $18 \%$ \\
\hline 5 & $\begin{array}{l}\text { Discussing } \\
\text { organizational issues }\end{array}$ & 186 & $100 \%$ \\
\hline 6 & $\begin{array}{l}\text { Providing extra information/ } \\
\text { further explaining issue }\end{array}$ & 28 & $15 \%$ \\
\hline 7 & Pre-closing & 48 & $26 \%$ \\
\hline 8 & Closing & 170 & $91 \%$ \\
\hline 9 & Signature & 180 & $96 \%$ \\
\hline
\end{tabular}

Discussion messages are the most common among all the informants; however, they were written regarding different issues. Most discussion messages that were written by the heads of program were regarding managerial issues like arrangements with internal and external partners. Administrative staff, however, were more engaged in discussing enrolment issues such as the registration of students in external exams, whereas the lecturers were engaged is discussing academic related issues with the students, and the assistant academic director was engaged in discussing complex managerial and administrative issues with external and internal contacts as in example 1.

CP: Discussing academic issues

M1: Identifying topic

M2: Salutation

M3: discussing

academic issue

M4: closing

M5: signature

CP: Communicative Purpose
Ex 1: 5.33. (superior, distant colleague, expertise, monthly)

From: VK

Sent: 26 May 2010 07:07

To: Kelly

Subject: Re: qualification assessment-CIF

Good morning Kelly.

According to your explanation, she cannot continue in diploma

2 because she did not complete diploma 1. But she has a

Bachelor in Computer science from university of computer studies, Dangon. And she already complete the first semester of diploma in Malaysia. It's impossible to ask her to do Diploma

1 in ABE. So please give some clarification and advise. thank you,

VK

Assistant Academic Director

CIF

Note: pseudonyms are used in the text 
As example 1 shows, Mr. VK, the assistant academic director of the institute, is engaged in a discussion regarding model exemption for one of the students with Kelly from ABE, UK. Obviously, there are contradicting points of view regarding the matter, which results in a longer exchange of email messages between the interactants - example 5.2 is the fourth in a seven-message chain of discussion messages. Kelly insists that the given student cannot join diploma two, before finishing diploma 1. Mr. VK, however, explains that the student obtained a bachelor in computer, and has already completed the first semester in diploma two before he transferred to the institute, so it is unreasonable to ask the student to start again from diploma 1. The issue in this discussion email, in fact, reflects the issues that Mr. VK is part of in the institute. As assistant academic director, he usually discusses issues regarding students' qualifications and registration with the external partners. As such, the majority of Mr. VK's discussion emails belong to long chains. In fact, Mr. VK was involved in two of the four longest chains of emails, which included from six to nine emails. Therefore, it is not surprising that the 38 discussion emails in Mr. VK's corpus concerned eight issues in eight chains of emails.

\subsection{Enquiry Messages}

Enquiry messages refer to the messages that are mainly requests or responding to requests in the workplace. They are the second most common communicative purpose of the email messages in the corpus. In fact, 33 percent (173 email messages) of the corpus belonged to this type of messages. This communicative purpose of email messages, as explained earlier, is divided into two sub-types that are the request and the response. The request is the main move in the first email that carries the enquiry, and the response is the main move in the second email in the chain that carries the reply. As both moves are closely related and the purpose of the second is responding to the first email, they are jointly identified as a single communicative purpose. In fact, the structure of requesting and responding to request type of communicative purpose seems close to turn taking in conversational discourse, as it is clear in example 2 and 3.

$\mathrm{CP}$ : Requesting action

M1: identifying topic

M2: Salutation

M3: requesting action

M4: closing

M5: signature

$\mathrm{CP}$ : Responding to request

M1: identifying topic

M2: responding to request

M3: closing

M4: signature

CP: Communicative Purpose
Ex 2: 6.17 (superior, senior, expertise, weekly)

Request for Photostat

On Mon, Mar 29, 2010 at 8:12 AM, HA 1 wrote:

Dear Iffat

Appreciate if you could photostat the following chapters of Operations Management

11. Supply Chain Management

Supplement Outsourcing

12. Inventory Managemen

thank you in advance

HA

Ex 3: 6.18. (subordinate, senior, expertise, weekly)

Re: Request for Photostat

From: Iffat

To: HA

Ok Mr. HA, will get it done.

Thanks

Iffat

Note: pseudonyms are used in the text

Example 2 is an email from a lecturer to Ms. Iffat, the administrative staff in the institute. Obviously, the email carries a single communicative purpose; that is, requesting action. The email included a proper salutation, closing and signature. The lecturer structured his request indirectly using the 'conditional if'. Example 3, however, is the response to the request in example 2. Ms. Iffat, the administrative staff acknowledges the request and assures the lecturer that she "will get it done". Even though the response email did not include a proper salutation as a separate move, it included the name of the requester proceeded by a formal title ' $M r$.', as a way of showing respect. The response email, however, included separate closing and signature moves. At the end of the response, example 5.4, it is obvious that the request was granted and the main purpose of example 2 is fulfilled.

It was noted that the 173 enquiry messages come in two main patterns that are (request-response-(thanking)) (RRT) or (request1-request2-response-(thanking)) (RRRT), where thanking in both patterns is optional. This underlying exchange structure in enquiry messages type is close to Sinclair and Coulthard's (1975) proposed structure of teacher-pupil talk (initiation-response-feedback) and Coulthard and Ashby's (1975) proposed structure of doctor-patient talk (initiationresponse-follow-up). Even though a written form, email, carries out the exchange, enquiry messages took a 
conversational pattern that depends on turn-talking between the requester and the responder. The requester fills the first and the third slots, and the first and the fourth slots in the second pattern, while the responder fills the second slot in the first pattern and the third in the second pattern. The second requester who either mistakenly received the request, or does not have the proper information to answer it, however, fills the second slot in the second pattern.

\section{The first pattern:}

\begin{tabular}{|c|c|c|}
\hline Requester & Request & Appreciate if you could Photostat the following chapters \\
\hline Responder & Response & OK, Mr. HA, will get it done \\
\hline Requester & Thanking & Thank you \\
\hline
\end{tabular}

The second pattern:

$\begin{array}{lll}1^{\text {st }} \text { requester: } & \text { Request } & \text { What is the USN number of the following student } \\ 2^{\text {nd }} \text { requester } & \text { Request } & \text { Please give them Ahmad's USN number } \\ \text { Responder } & \text { Response } & \text { The following is the USN number of the student } \\ 1^{\text {st }} \text { requester } & \text { Thanking } & \text { Thank you }\end{array}$

Enquiry messages incorporated nine moves, which are six framing and three content moves (See Table 3).

Table 3. Moves in enquiry messages

\begin{tabular}{|c|c|c|c|}
\hline No & Moves & $\begin{array}{l}\text { Occurrences ( out of } \\
173 \text { emails) }\end{array}$ & Percentage \\
\hline 1 & Identifying topic & 171 & $99 \%$ \\
\hline 2 & Salutation & 136 & $79 \%$ \\
\hline 3 & Opening & 2 & $1 \%$ \\
\hline 4 & Referring to issue/ contact & 23 & $13 \%$ \\
\hline 5 & $\begin{array}{l}\text { Requesting/ responding to } \\
\text { request }\end{array}$ & 173 & $100 \%$ \\
\hline 6 & $\begin{array}{l}\text { Providing extra information/ } \\
\text { explaining issue }\end{array}$ & 14 & $15 \%$ \\
\hline 7 & Pre-closing & 25 & $20 \%$ \\
\hline 8 & Closing & 138 & $80 \%$ \\
\hline 9 & Signature & 159 & $92 \%$ \\
\hline
\end{tabular}

The three content moves are the main move of the communicative purpose that is 'requesting or responding to requests', which appeared in all enquiry messages, an intertextual move that related the email to previous correspondence and the supporting move that was mainly used to further explain the main move. As discussion messages, enquiry messages included six framing moves. Comparing the frequency of using framing moves between enquiry and discussion messages shows that the frequency of using these moves in discussion messages is higher than in enquiry messages. It is believed that the main purpose of using less framing moves in enquiry messages than discussion messages is that more discussion messages were sent or received by external contacts than enquiry messages. In fact, 75 percent of enquiry messages were exchanged between internal staff, whereas 69 percent of discussion messages were exchanged between internal staff. That is, it is believed that the respondents are more polite to external contacts than they are to internal contacts.

\subsection{Courier messages}

Courier messages refer to the messages that were sent to deliver documents or forms. They are the third most common communicative purpose in the corpus as 17 percent ( 89 messages) of the emails belong to this communicative type. The main content move of courier messages, which carries the communicative purpose of the email, is indicating enclosure'. As the name suggests, this move is used to draw the attention of the recipient from the content of the message to the enclosed file[s]. 
Table 4. Moves in courier messages

\begin{tabular}{llll}
\hline No & Moves & $\begin{array}{l}\text { Occurrences (out of 89 } \\
\text { emails) }\end{array}$ & Percentage \\
\hline 1 & Identifying topic & 89 & $100 \%$ \\
2 & Salutation & 71 & $80 \%$ \\
3 & Opening & 1 & $1 \%$ \\
4 & Indicating enclosure & 89 & $100 \%$ \\
5 & offering help if needed & 17 & $19 \%$ \\
6 & Providing extra information/ & 37 & $42 \%$ \\
& further explaining issue & & \\
7 & Requesting confirmation & 9 & $10 \%$ \\
8 & Pre-closing & 9 & $10 \%$ \\
9 & Closing & 71 & $80 \%$ \\
10 & Signature & 76 & $85 \%$ \\
\hline
\end{tabular}

Overall, courier messages included ten moves that are six framing moves and four content moves. The four content moves are the 'indicating enclosure' which is the main communicative move of the communicative purpose, one supporting move, 'providing extra information', and two follow-up moves that are 'offering help' and 'Requesting confirmation' moves (see table 4 above).

As the table shows, courier messages, unlike discussion and enquiry messages, did not include the intertextual move 'referring to previous contact'. The main purpose of not including this move is that this type of messages is mainly a solitary type that does not belong to chains. However, it was found that the some of the courier messages were followed by a confirming receipt email. The most common supporting content move was 'providing extra information/ explaining issue'. The main function of this move is to explain the content of the attachment. Even though this move was not very frequent, as it appeared in 42 percent of the messages, it has a very important role as it explains the content of the attached file. 'Requesting confirmation' and 'offering help' follow-up moves were the other two content moves that occurred in 9 and 17 percent of the emails respectively. The main function of the first move is to confirm that the email recipient has received the attached file. The emails that included this move were mainly followed by a confirming receipt email. The 'offering help' move also functioned as a follow-up move that encourages the recipient to ask for clarifications or explanations regarding the attached files, if needed.

Examining the framing moves in courier messages shows that the six framing moves used almost had the same level of frequency as in enquiry messages. As enquiry messages, more courier messages were sent to internal than external contacts, which explains the relatively low frequency of salutation, closing, and signature moves. The 'identifying topic' move, however, enjoyed a 100 percent frequency. Examining the use of the 'identifying topic' move showed as interesting finding that relates it directly to the main content move of courier messages. In fact, 20 percent of courier messages did not include a salutation, closing or any kind of information regarding the content or the nature of the document in the body of the email. The only content move was a 'requesting-like-directing' move that directs the attention of the recipient to the attachment, 'please find attached'. This shows that the 'directing move' did not include any beneficial input about the nature or the content of the attached file. The only reference to the content or the nature of the enclosed file was found in the identifying topic move in the subject box of the email (see example 4).

\begin{tabular}{|c|c|}
\hline $\begin{array}{l}\text { CP: Delivering } \\
\text { documents }\end{array}$ & Ex 4: 2.46. (subordinate, distant colleague, monthly) \\
\hline M1: identifying topic & Subject: new syllabus and lecturer guides for new TTH \\
\hline $\begin{array}{l}\text { M2: Indicating } \\
\text { enclosure }\end{array}$ & $\begin{array}{l}\text { management programme } \\
\text { find attached }\end{array}$ \\
\hline M3: closing & Regards \\
\hline M4: auto signature & Auto signature \\
\hline
\end{tabular}

As example 4 shows, the email included four moves, only one of which is a content move. The only content move, 'find attached', is a directing move that does not explain a thing about the attached file. However, as the email shows, the 'identifying topic' move, in the subject box of the email, included a full description about the attached file. This shows the special importance and the key role played by the 'identifying topic' move in this type of messages. This practice, in fact, appeared in 25 percent of courier messages. 


\subsection{Informing messages}

Informing messages are the messages that are mainly sent to inform, notify, or update the recipient[s] about a general interest issue. They are the fourth and the last communicative purpose of the corpus. In fact, seventy-four email messages (14 percent) belong to this communicative purpose. Examining the move structure of informing messages show that they included nine communicative moves, which are four content and five framing moves. The main communicative move of informing messages is 'informing about academic or organizational issues', which appeared in all the 74 informing messages (see table 5).

Table 5. Moves in informing messages

\begin{tabular}{|c|c|c|c|}
\hline No & Moves & $\begin{array}{l}\text { Occurrences (out of } \\
74 \text { emails) }\end{array}$ & Percentage \\
\hline 1 & Identifying topic & 74 & $100 \%$ \\
\hline 2 & Salutation & 74 & $100 \%$ \\
\hline 3 & $\begin{array}{l}\text { Informing about academic/ } \\
\text { organizational issues }\end{array}$ & 74 & $100 \%$ \\
\hline 4 & Providing extra information & 35 & $47 \%$ \\
\hline 5 & Requesting Confirmation & 23 & $31 \%$ \\
\hline 6 & Offering help if needed & 11 & $15 \%$ \\
\hline 7 & Pre-closing & 14 & $19 \%$ \\
\hline 8 & Closing & 71 & $96 \%$ \\
\hline 9 & Signature & 73 & $99 \%$ \\
\hline
\end{tabular}

As Table 5 shows, the writers of informing messages used the 'providing extra information' supporting move and 'offering help' and 'requesting confirmation' follow-up moves. The function of 'providing extra information' content move is to further explain the main content move of the email. This move was presented by giving extra details regarding the main issue of the email. The use of the 'offering help' content move, as in courier messages, was giving the chance to the recipient to ask for clarification if needed. The 'requesting confirmation' content move, however, appeared in 23 informing messages to motivate the recipient to confirm the receipt of the message and the information. Nevertheless, it was noticed that informing messages were mainly a solitary type of email that did not require a reply.

Examining the use of framing moves in informing messages shows that they included the highest frequency and occurrence of framing moves among the four different communicative purposes. The 'identifying topic' and salutation framing moves enjoyed a 100 percent occurrence, whereas the closing and signature moves appeared in 96 and 99 percent of the emails respectively, which reflects the very high framing formality in informing messages. In fact, the formality of the framing moves in informing messages is comparable to the framing structure of formal letters and memorandums.

Examining the use of informing messages shows that they are mainly sent to a number of recipients at the same time informing about a general interest issue. In fact, informing messages are the only communicative purpose in the corpus that directly targets a number of recipients. It was observed that this type of messages was mainly sent to groups of students, lecturers, employees and collaborated partners to inform, notify, or update them regarding an issue that interests all of them (see example 5).

$\begin{array}{ll}\begin{array}{l}\text { CP: Informing about } \\ \text { academic issues }\end{array} & \text { Ex 5: 3.62. (superior, daily) } \\ \begin{array}{l}\text { M1: identifying topic } \\ \text { M2: Salutation }\end{array} & \text { Fw: emarketing and entrepreneurship class } \\ \text { M3: informing about } & \text { Dear Students } \\ \text { academic issue } & \text { Emarketing and Entrepreneurship class is on from this week } \\ \text { M4: closing } & \text { onwards, 16th May 2010, 2pm to 6pm. Lecturer is Mr. XX } \\ \text { M5: auto signature } & \text { Thanks }\end{array}$

CP: Communicative Purpose

As example 5 shows, the email was sent from the head of academic studies to the students of 'E-marketing and Entrepreneurship'. The email carries a single purpose that is, informing the students about the commencing date, the time and the name of the lecturer. Even though the salutation is directed to 'students' in general, it is obvious from the identifying topic move and the first sentence in the email that the concerned students are the students enrolled in the named module. As the function of the email is to inform, the language is direct and informative. The email has proper 
framing moves. Obviously, the identifying topic move carried the main communicative purpose of the email that is concerning the commencement of the class.

\section{Comparison and Contrast between the Four Communicative Purposes}

The rhetorical or the structural organization analysis of the 522 email messages revealed four different communicative purposes. These communicative purposes appear to converge and diverge in the type and frequency of the communicative moves that accompany the main communicative move carrying the communicative purpose. The analysis also revealed that the four communicative purposes vary in the number of their recipients and the reaction to receiving the message.

Examining the content communicative moves that convey the four communicative purposes shows that only discussion and enquiry messages included the intertextual move 'referring to previous contact'. Examining these two communicative purposes shows that they are always part of chains. As such, the main communicative intention of this intertextual move is relating the written email to previous messages or correspondence. However, as courier and informing messages did not usually belong to chains, they did not include this move.

Courier and informing messages, however, included 'requesting confirmation' and 'offering help' follow-up moves. The main purpose of including these two moves in these two communicative purposes is that these types of messages do not usually require a reply. As such, the writers of these two communicative purposes wanted to take the initiative to motivate a reply by requesting confirmation and/or by offering help if needed. Discussion and enquiry messages, however, did not include these two moves as the response to these communicative purposes is an expected practice by the writers.

In addition to these moves, it is observed that writers of the four communicative purposes used the 'providing extra information/further explaining the issue' move. Overall, the use of this supporting move is more common in the corpus than the number of courier and informing messages. This move appeared in 37, 35, 29, and 14 courier, informing, discussion and enquiry messages, respectively. As the main communicative function of this move, as the name suggests, is further elaborating on the issue of interest, the 37 (42 percent) and 35 (47 percent) occurrences in courier and informing messages respectively is justified. That is, as courier and informing messages do not usually require a reply and included specific information or attached documents, the writers of these two communicative purposes wanted to fully explain the attributed issue or the attached document, before sending the emails. Obviously, the writers wanted to clarify any confusion or misunderstanding that may arise if the issue was not fully explained. However, as discussion and enquiry messages always created a reply, the use of this move was not very popular. It occurred in 15 percent of discussion and enquiry messages.

Overall, all the four different types of communicative purposes enjoyed a high frequency of the main framing moves that are the identifying topic move, salutation, closing, and signature. However, the identifying topic and signature moves were the most common moves in the four different types of communicative purposes. Given that the identifying topic move stands as a 'reference' to the email and the signature stands as a 'personal identification' move explains the special importance of these two moves, especially in the organizational context where the identity and the organizational position of the person reflects his/ her eligibility to acquire or have access to the specific information.

Regarding the number of recipients, it is found that discussion, enquiry and courier messages were mainly sent to a single recipient. However, there were a number of instances where these types of messages, especially discussion messages, were sent to a third or fourth person using the ' $C C$ ' option in the formatting structure of the email. The main purpose of sending this type of messages to another recipient was bringing the attention of the management to the attributed issue. Informing messages, however, mainly targeted a number of recipients to inform, notify or update them regarding general interest issue. This practice adds to the importance of informing messages for the discourse community in the institute since they stand as a 'noticeboard' (Kankaanranta, 2005) that includes the latest changes and developments.

\section{Conclusion}

The investigation of the moves and communicative purposes used in the 522 email messages exchanged in a private educational institute in Kuala Lumpur shows that the emails were used to communicate four main communicative purposes. Email writers used email to discuss issues, enquire about issues, courier documents or files or inform about academic or organizational issues. Examining the use of those four communicative purposes demonstrated that they vary in their rhetorical or organizational structure, reaction to receiving the email and the number of recipients.

It appeared that discussion and enquiry messages always belong to chains, courier and informing messages, however, appeared to be solitary communicative purposes that did not need a reply. Examining the target group of these messages shows that discussion, enquiry and courier messages mainly targeted a single recipient to discuss, request, or send a document. Informing messages, however, mainly targeted groups of recipients that consisted of students, lecturers, colleagues, or partners. It was also noticed that informing and courier messages were mainly written by administrative staff, discussion and enquiry messages, however, were written by the all informants represent the different organizational positions. 


\section{References}

AlAfnan, M. A. (2015). Asynchronous communication: Investigating the influences of relational elements and background on the framing structure of emails. Advances in Language and Literary Studies. 6(2), 44-50. Doi: 10.7575/aiac.alls.v.6n.2p.44

AlAfnan, M. A. (2015, in press). Analyzing the rhetorical, typographical and paralinguistic features of electronic mails in the workplace. International Journal of Applied Linguistics \& English Literature, 4(4)

AlAfnan, M. A. (2014a). Politeness in Business Writing: The Effects of Ethnicity and Relating Factors on Email Communication. Open Journal of Modern Linguistics, 4(2), 275-289. doi: 10.4236/ojml.2014.42022

AlAfnan, M. A. (2014b, March 27-28). Interethnic workplace communication: An investigation into politeness strategies. Proceedings of the 2014 International Conference on Public Management and Education Research in Tianjin, China (iceeim-14). doi:10.2991/iceeim-14.2014.61

Askehave, I., \&, Nielsen, A. E. (2005). Digital genres: A challenge to traditional genre theory. Information Technology \& People, 18(2), 120 - 141. doi: 10.1108/09593840510601504

Berkenkotter, C., \& Huckin, T. N. (1995). Genre knowledge in disciplinary communication: Cognition/culture/power. Hillsdale, NJ: Erlbaum.

Bhatia, V. K. (1993). Analysing genre: Language use in professional settings. London, England: Longman.

Bhatia, V. K. (2002). Applied genre analysis: Analytical advances and pedagogical procedures. In A. M. Johns (Ed.), Genre in the classroom: Multiple perspectives (pp. 279-283). Mahwah, NJ: Erlbaum.

Bhatia. K. (2004). Worlds of written discourse: A genre-based view. London, England: Continuum International.

Borg, E. (2003). Key concepts in ELT: Discourse community. ELT Journal, 57(4), 398-400. Retrieved from http://sullivanfiles.net/WID/assignments/discourse_field/borg_discoursecommunity pdf

Coulthard, M., \& Ashby, M. (1975). Talking with the doctor. Journal of Communication, 25(3), 140-148. doi: 10.1111/j.1460-2466.1975.tb00616.x

Daft, R. L., \& Lengel, R. H. (1986): Organizational information requirement, media richness and structural determinants. Management Science, 32, 554-571 doi: 10.1287/mnsc.32.5.554

Fairclough, N. (1995). Critical discourse analysis: The critical study of language. London, England: Longman.

Fish, S. (1980). Is there a text in this class? The authority of interpretive community. Cambridge, MA: Harvard.

Friesen, N. (2009). Genre and CSCL: The form and rhetoric of the online posting. Computer-Supported Collaborative Learning, 4, 171-185. doi: 10.1007/s11412-009-9060-1

Hymes, D. (1972). On communicative competence. In Pride, J. and Holmes, J. (Eds.) Sociolinguistics (pp. 269-293). Harmondsworth, Middlesex: Penguin.

Kankaanranta, A. (2005). English as a corporate language: Company-internal email messages written by Finns and Swedes. In B-L. Gunnarsson, (Ed.), Communication in the workplace (pp. 42-59), TeFa Nr 42, Uppsala, Sweden: Uppsala University Press.

Lassen, I. (2006). Is the press release a genre? A study of form and content. Discourse Studies, 8(4), 503-530. doi: $10.1177 / 1461445606061875$

Llopis., M. A. O. (2009). Legal genres in English and Spanish: Some attempts of analysis. IBÉRICA, 18, $109-130$. Retrieved from http://www.aelfe.org

Louhiala-Salminen, L. (1995). Drop me a fax, will you? A study of written business communication. Reports from the Department of English, University of Jyväskylä (No. 10, p. 115). Jyväskylä, Finland: University of Jyväskylä

Louhiala-Salminen, L. (1999). From business correspondence to message exchange: The notion of genre in business communication. Unpublished doctoral dissertation, University of Jyväskylä, Sweden.

Markus, M. L. (1994). Electronic mail as the medium for managerial choice. Organization Science, 5, 502-527. doi: 10.1287/orsc.5.4.502

Martin, J. R. (1985). Process and text: Two aspects of human semiosis. In J.D. Benson \& W.S. Greaves (Eds.), Systemic Perspectives on Discourse (Vol. 1, pp. 248-274.). Norwood, NJ: Ablex. doi. 10.1336/0893911933

Miller, C. R. (1984). Genre as social action. Quarterly Journal of Speech, 70, 151-167. doi: $10.1080 / 00335638409383686$

Mulholland, J. (1999). E-mail: Uses, issues and problems in an institutional setting. In F. Bargiela-Chiappini \& C. Nickerson (Eds.), Writing business: Genres, media and discourses (pp. 57-84). London, England: Longman.

Nor Azni Abdullah. (2003). Relational communication in organization E-mail: A Malaysian case study. Unpublished $\mathrm{PhD}$ dissertation, University of Malaya, Malaysia.

Nor Azni Abdullah. (2006, December). Constructing business email messages: A model of writers' choice. ESP Malaysia, 12, 53-63. Retrieved from http://www.penerbit.utm.my/OnlineEspMalaysia/12/Artikel_53_63.pdf

Sinclair, J., \& Coulthard, M. (1975). Towards an analysis of discourse. Oxford, England: Oxford University Press. 
Spooner, M, \& Yancey, K. (1996). Postings on a genre of email. College Composition and Communication, 47, 252278. doi: $10.2307 / 358795$

Swales, J. M. (1990). Genre analysis. English in academic and research settings. Cambridge, England: Cambridge University Press.

Swales, J. M. (1998). Other floors, other voices: A textography of a small university building. Mahwah, NJ: Erlbaum.

Wang Ji-yu (2007). Genre analysis on business English correspondence. Sino-US English Teaching, 4(12), $42-47$. Retrieved from http://www.linguist.org.cn/doc/su200712/su20071210.pdf

Yates, J. \& Orlikowski, W. J. (1992). Genres of organizational communication: A structurational approach to studying communication and media. Academy of Management Review, 17(2), 299-326. doi: 10.2307/258774

Yates, J., \& Orlikowski, W. J. (2002). Genre systems: Structuring interaction through communicative norms. Journal of Business Communication, 39, 13-35. doi: 10.1177/002194360203900102. 